\title{
Effect of urbanization and feeding intensity on the distribution of wintering Mallards Anas platyrhynchos in NE Poland
}

\author{
Effekt av urbanisering och matning på förekomsten av övervintrande gräsänder \\ Anas platyrhynchos $i$ nordöstra Polen
}

MICHAŁ POLAKOWSKI, MICHAŁ SKIERCZYŃSKI \& MONIKA BRONISZEWSKA

\begin{abstract}
Urban areas are alternative wintering sites for species with ability to exploit the new conditions that cities offer, such as food, shelter and reduced predation. During four winters (November-February), we recorded the number of Mallards along $108 \mathrm{~km}$ of rivers within an urbanization gradient from city centre to rural in north-east Poland. In the urban area, but not in the suburban and rural areas, there was an increase of numbers through winter with highest numbers in February, the coldest month. However, we found no correlation between numbers and ice cover. The only correlation was with feeding intensity by humans, and we suggest that intensity of feeding and the location of the feeding sites is the main factor determining number of wintering Mallards. This was sup-

ported by recoveries of ringed birds. Mallards ringed at good feeding sites in the city centre were recovered at the same sites whereas birds ringed in the periphery of the city tended to move to the centre in subsequent winters.

Michat Polakowski and Monika Broniszewska, Zachodnia 30A/8, PL-15-345, Biatystok, Poland. E-mail: polnocne.podlasie@gmail.com

Michat Skierczyński, Department of Behavioural Ecology, Institute of Environmental Biology Faculty of Biology, Adam Mickiewicz University, Umultowska 89, PL-61-614, Poznań, Poland.

E-mail:michskie@amu.edu.pl
\end{abstract}

\section{Abstract}

Received 20 April 2010, Accepted 15 June 2010, Editor: S. Svensson

\section{Introduction}

Adaptation to urban ecological niches requires changes in the behaviour and ecology of species primarily occupying non-urban (rural and wild) areas. For example, urban populations of Blackbird Turdus merula, Mallard Anas platyrhynchos, Coot Fulica atra, Mute Swan Cygnus olor, and Rook Corvus frugilegus in Central Europe usually spend winters in their urban breeding areas, while rural populations of these species migrate over long distances to their wintering sites (review in Luniak 2004). Reduction of seasonal migrations is a consequence of better wintering conditions within cities, particularly related to the milder urban microclimate, providing snow-free spaces and ice-free waters (Avilova 2008, Brauze \& Kurkowski 2008).

The urban populations of these species are usually characterized by a year-round high population density, mainly due to lower predation pressure and rich anthropogenic food resources (leftovers, feeding by people). Such opportunities are attractive to many bird and mammal species, leading to changes in their feeding behaviour (Guillemain et al. 2002, Charalambidou et al. 2005, Jones \& Reynolds 2008). In the Mallard, anthropogenic food resources contribute to a substantial (sometimes the main) diet component, particularly during winters (Polańska \& Meissner 2008). The distribution of feeding sites as well as the feeding intensity are important factors affecting abundance and density of Mallards during winter periods (Jones \& Reynolds 2008). In the breeding season it is the availability of suitable nesting sites, dispersed within the matrix of built-up areas, that determines the density of urban populations (Huhtalo \& Järvinen 1977).

The Mallard seems to be a species that has adapted particularly well to urban conditions across Europe (Cramp \& Simmons 1977, Engel et al. 1988, Luniak 2006). In Poland it is reported as the most numerous over-wintering species (e.g. Brewka 1993, Mazurek \& Polakowski 2002, Piotrowska 2003, Tomiałojć \& Stawarczyk 2003, Zieleniak 2007, Ławicki et al. 2008), which can be observed in urban areas (Hebda 2001, Biaduń 2005, Luniak 2006). However, we are not aware of any study of 


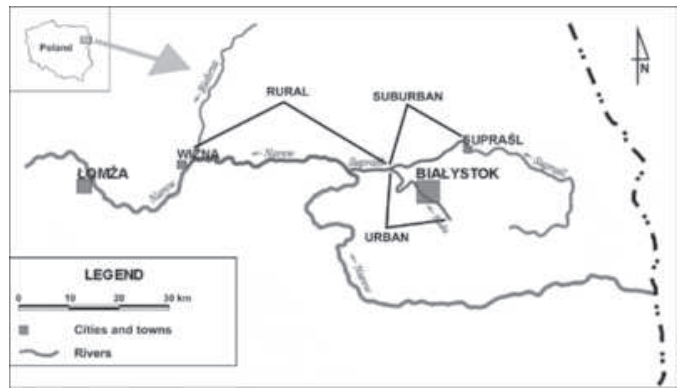

Figure 1. Study area. Undersökningsområde.

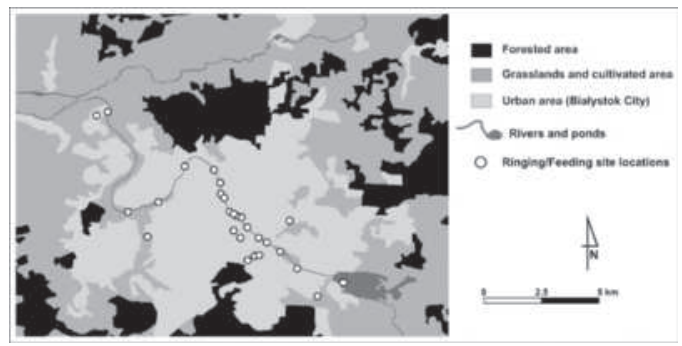

Figure 2. Locations of ringing and feeding sites in the Białystok City.

Lokalisering av platser för ringmärkning och matning $i$ Białystok (små cirklar). Svart är skog, mörkgrått jordbruksmark och ljusgrått tätort.

as well as the feeding intensity, expressed as the number of people feeding birds per one hour. A total of 225 Mallards was ringed. They were trapped using a loop-trap made of a fishing line of $0.33 \mathrm{~mm}$ diameter, placed on the ground across the ducks' usual route to the water and with bait in the loop. The observer then pulled the line that tightened on the bird's leg. This method is successfully applied in Poland for capturing ducks (Anas sp.), geese (Anser sp. and Branta sp.), gulls (Larus sp.) and other birds (M. Polakowski - own unpublished data), and performed by an experienced person this method is equally safe for birds as other capturing techniques.

Statistical tests were performed using KruskalWallis non-parametric analysis of variance and Friedman test in SPSS 12.0 PL for Windows.

\section{Results and discussion}

The number of wintering Mallards differed between the habitat categories (Figure 3). Most Mallards wintered in the urban area (Białystok City). The smallest numbers were found in the suburban area, whereas rather high numbers were recorded in the rural area (Narew River).

Mallard abundance did not differ significantly between winters in any of the three considered areas when data from all months were pooled (Figure 3). However, we observed significant increase in the number of individuals in the urban area from November to February $(\rho=0.679, p<0.01)$, whereas numbers remained similar throughout the winter in suburban and rural areas. The increase of the number of individuals during the winter in the urban area was probably caused by relatively little ice on rivers within the city, compared to suburbs 


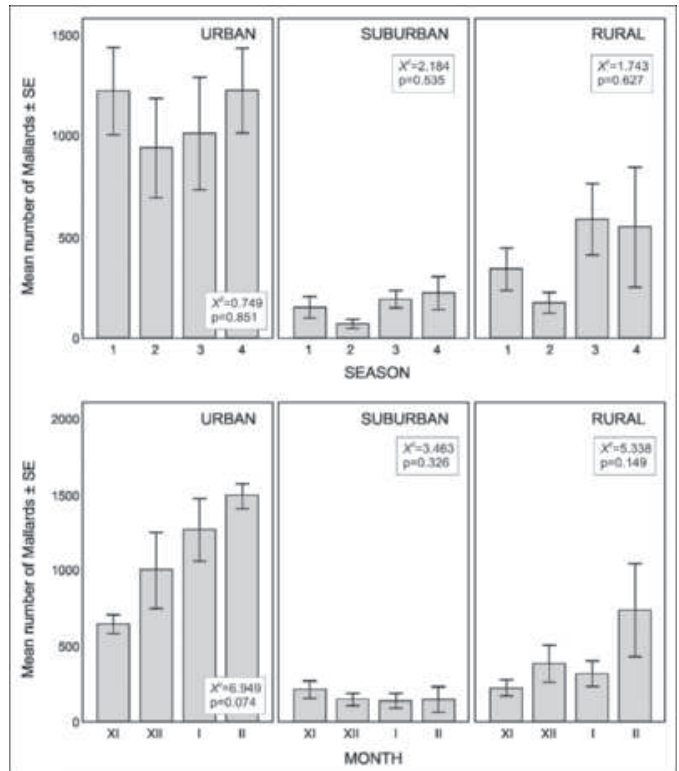

Figure 3. Comparison of mean numbers of wintering Mallards between different winter seasons (upper) and months (lower) under various urbanisation gradients.

Medeltal övervintrande gräsänder olika vintrar (överst) och månader (nederst) $i$ biotoper med olika grad av urbanisering.

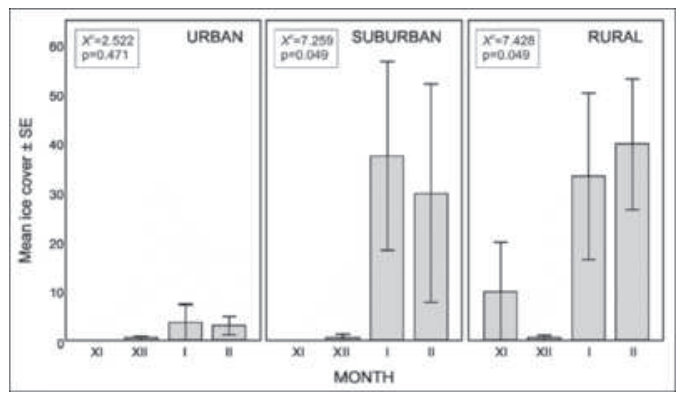

Figure 4. Mean ice cover (percent) in different months in the three habitats with different level of urbanisation.

Istäckning (procent) olika månader inom de tre områdena med olika urbanisering.

and rural area (Figure 4). However, no significant effect of ice cover could be found when this was tested.

There were no significant differences in the mean feeding intensity between months $\left(\chi^{2}=0.018, \mathrm{df}=\right.$ $3, \mathrm{p}=0.895)$. We found that Mallard abundance was positively correlated with feeding intensity $(\rho$
$=0.534, \mathrm{p}<0.01)$. Sites with highest feeding intensity (from 4.0 to 5.0 persons per hour), were mostly found in the city centre, while low feeding intensity sites (from 0.5 to 1.5 persons per hour) were located in the peripheral area of the city. We assumed that no feeding occurred in the suburban and rural areas, since we did not observe such activities during field surveys.

Twenty-four ringed Mallards were recaptured in a subsequent winter. Fourteen of them were both ringed and recovered in the city centre. Eight birds that had been ringed in the periphery of the city were recovered at feeding sites in the centre. The remaining two recoveries were made in the city periphery. Individuals ringed at low feeding intensity sites (regardless whether it was the city centre or the periphery) were recovered at sites where feeding intensity was higher than at the ringing site (Figure 5).

The facts that we could find no significant effect of ice cover, the tendency of recovered birds to move from poorer to better feeding sites, and the strong increase of birds in the urban area (they gathered in the city centre where the feeding intensity was highest as the winter became colder) suggest that the main factor affecting wintering Mallard abundance was the location of feeding sites and feeding intensity.

We also observed that during the coldest months (bigger ice cover in sub-urban and rural areas than in the city centre) a high number of Mallards moved into the urban area, reaching the maximum number ever recorded during this study. This suggests that birds from outside the study area were also winter-

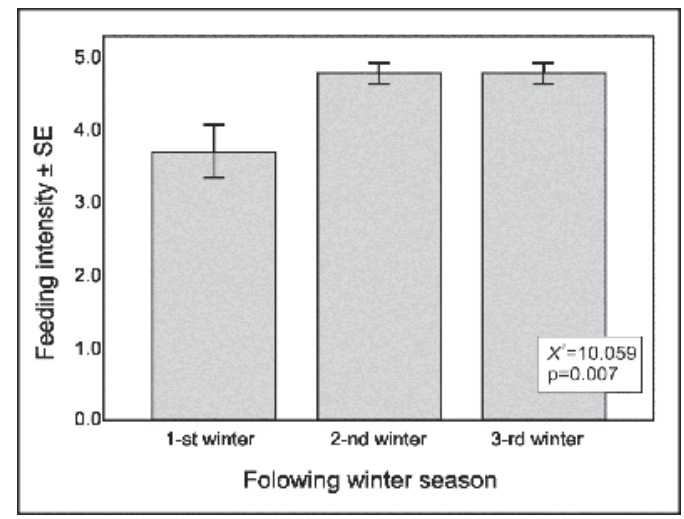

Figure 5. Mallard feeding site choice in following winter seasons.

Val av födosöksområde vinter efter märkning. 
ing in the city. This observation can be explained by the migration of birds that usually winter in artificial lakes and ponds around the city. When these lakes had frozen, birds moved into the city which was the closest alternative wintering site.

Our results suggest that both the density and the distribution of wintering Mallards in urban areas are determined mainly by the intensity of feeding and the location of feeding sites. We found that Mallards ringed at good feeding sites in the city centre were recovered at the same sites in subsequent seasons, while birds ringed in the peripheral area tended to move to the centre during the following winters. Moreover, our results show an interesting foraging behaviour of Mallards, where individuals were able to localise good feeding sites from one winter season to another.

\section{Acknowledgements}

We want to thank numerous people from The Polish Society for Birds Protection and the Biology Students Scientific Circle at the Institute of Biology, University of Bialystok for their assistance in the field work.

\section{References}

Avilova, K.V. 2008. Number of waterfowl wintering in Moscow (1985-2004): dependence on climate conditions. Revista Catalana d'Ornitologia 24: 71-78.

Biaduń, W. 2005. Winter avifauna of Lublin - species composition, distribution and numbers. Berkut 14: 1-23.

Brauze, T. \& Kurkowski, Ł. 2008. The environmental factors influencing the similarity of species composition of winter bird communities in Toruń town. In: Fauna miast. Ochronić różnorodność biotyczną $\mathrm{w}$ miastach. Indykiewicz P., Jerzak L., Barczak T. (Ed.), 44-50. SAR „Pomorze”, Bydgoszcz.

Brewka, B. 1993. Zimowanie krzyżówki (Anas platyrhynchos) na Zatoce Gdańskiej w sezonach 1984/1985 1986/1987. Notatki Ornitologiczne 34: 55-62.

Charalambidou, I., Santamaria, L., Jansen, C. \& Nolet, B.A. 2005. Digestive plasticity in Mallard ducks modulates dispersal probabilities of aquatic plants and crustaceans. Functional Ecology 19: 513-519.

Cramp, S. \& Simmons, K.E. (Ed.) 1977. The Birds of the Western Palearctic. Oxford University Press, Oxford.

Engel, J., Keller, M., Leszkiewicz, J. \& Zawadzki. J. 1988. Synurbization of the mallard Anas platyrhynchos in Warsaw. Acta Ornithologica 24: 9-28.

Guillemain, M., Fritz, H. \& Duncan, P., 2002. Foraging strategies of granivorous dabbling ducks wintering in protected areas of the French Atlantic coast. Biodiversity and Conservation 11: 1721-1732.

Hebda, G. 2001. Migration and wintering of waterfowls in the Odra River in the Opole city. Opolskie Towarzystwo Przyjaciół Nauki, Zeszyty Przyrodnicze 35: 62-71.
Huhtalo, H. \& Järvinen, O. 1977. Quantitative Composition of the Urban Bird Community in Tornio, Northern Finland. Bird Study 24: 179-185.

Jones, D.N. \& Reynolds, S.J. 2008. Feeding birds in our towns and cities: a global research opportunity. Journal of Avian Biology 39: 265-271.

Luniak, M. 2004. Synurbization - adaptation of animal wildlife to urban development. In: Shaw, W.W, Harris, K.L., Van Druff, L., (Ed.). Urban wildlife conservation. Proceedings of the 4-th International Urban Wildlife Symposium: 50-55. University of Arizona, Tucson, UAS.

Luniak, M. 2006. Bogactwo gatunkowe i liczebność fauny wielkiego miasta-przykład Warszawy. Kosmos 55: 45-52.

Ławicki, Ł., Czeraszkiewicz, R., Guentzel, S., Jasiński, M., Kajzer, Z., Kaliciuk, J. \& Oleksiak, A., 2008. Zimowanie ptaków wodnych na Pomorzu Zachodnim w latach 2002 2008. Notatki Ornitologiczne 49: 235-244.

Mazurek, Ł. \& Polakowski, M. 2002. Liczenie Ptaków Zimujących na Nizinie Północnopodlaskiej w sezonie 2001/2002. Materiały VI Ogólnopolskiego Przeglądu Działalności Kół Naukowych Przyrodników, 105-110. Wydawnictwo Akademii Pedagogicznej, Kraków.

Piotrowska, M. 2003. Zimowanie ptaków wodnych na Wiśle Środkowej w latach 1985-2000. Notatki Ornitologiczne 44: 138-146.

Polańska, H. \& Meissner, W. 2008. Techniki zdobywania pokarmu stosowane przez krzyżówki Anas platyrhynchos w parku miejskim w okresie pozaleggowym. In: Fauna miast. Ochronić różnorodność biotyczną w miastach. Indykiewicz P., Jerzak L., Barczak T. (Ed.), 524-529. SAR „Pomorze”, Bydgoszcz.

Tomiałojć, L. \& Stawarczyk, T. (Ed.) 2003. The Avifauna of Poland. Distribution, numbers and trends. PTPP ,pro Natura", Wrocław.

Zieleniak, A. 2007. Liczenie zimujących ptaków wodnobłotnych w Regionie Łódzkim. Biuletyn Faunistyczny Polski Środkowej 13: 5-7.

\section{Sammanfattning}

De fåglar som anpassat sig till tätorternas annorlunda ekologiska nischer har ofta andra vanor än sina artfränder på landsbygden eller ute i den vilda naturen. Exempelvis övervintrar fåglar som häckar i tätorter i högre grad än de som lever på landsbygden, vilka kan flytta långa sträckor. Arter som i hög grad anpassat sig till urbana miljöer är bl.a. koltrast, sothöna, knölsvan och råka. De har funnit gynnsamma betingelser för övervintring och har ofta tätare bestånd året runt i städerna än uti i naturen. Beroende på art kan orsaken vara gynnsammare mikroklimat, lägre predation eller ett rikare utbud av föda. Gräsanden är en annan art som särskilt väl anpassat sig till urbana förhållanden vintertid på många håll i Europa. Exakt vad som bestämmer antalet övervintrande gräsänder är dock mindre väl känt, och särskilt vilken betydelse som människans utfodring har.

Vi studerade de övervintrande gräsänderna i nor- 
ra Podlasie i nordöstra Polen, den kallaste delen av landet nedom bergen. Data insamlades under 2-4 dagar i mitten av varje månad från november till februari under fyra vintrar (2005/2006-2008/2009). Räkningarna utfördes längs 108 kilometer flodsträckor, som delades upp i tre grader av urbanisering utifrån omgivningarna: urban (city), suburban och rural (landsbygd). Antalet gräsänder räknades $i$ alla tre miljöerna. I den urbana delen registrerade vi också matningen i form av antal personer som matade per timme på olika ställen. Vi fångade och märkte gräsänder på olika platser i den urbana delen, både i centrum och i periferin. Vi registrerade också isläget vid varje tillfälle och på varje plats. Totalt märktes 225 gräsänder.

Antalet övervintrande gräsänder skilde sig mellan de tre biotoperna (Figur 3). De högsta antalen fanns i Białostok centrum och de lägsta på platser i de suburban miljöerna. Däremot fanns ganska många där floder rann genom landsbygd. Det var ingen skillnad i antal mellan vintrarna när man slog ihop alla månader. Däremot noterade vi en signifikant ökning under vinterns lopp i stadsmiljön med högst antal i februari, den kallaste månaden. Möjligen kunde detta bero på mindre is på floden i cen- trum, men vi fann dock ingen statistiskt signifikant effekt av isläget.

Vi registrerade inga skillnader i matningsintensitet mellan olika månader. Men gräsändernas antal var signifikant korrelerat till människornas matningsintensitet, och denna var högst just i centrum men lägre mot periferi i den urbana miljön. Vi tror att det inte förekom någon matning i den suburbana och rurala miljön, något som vi dock inte studerade.

Märkningarna resulterade i 24 återfångster ett senare år. Fjorton fåglar både märktes och återfångades på samma platser i centrum. Åtta fåglar som märkts i periferin återfångades i centrum. De återstående två fåglarna återfångades i periferin. Oberoende av var de märkts återfångades fåglarna på platser där det var högre matningsintensitet än där de märkts (Figur 5).

Det faktum att vi inte fann något signifikant samband med istäckningen, tendensen att fåglarna flytta från sämre till bättre matplatser och den kraftiga ökninen av gräsänder i centrum under den kallaste månaden tolkar vi som att huvudfaktorn som bestämmer antal och plats för övervintring var människornas matning. 